\title{
The application of disaster management in Turkey from a comparative perspective: a proposal for a new model
}

\author{
I. Gunduz ${ }^{1} \&$ B. Parlak ${ }^{2}$ \\ ${ }^{I}$ Governorship of Buyukcekmece District, Turkey \\ ${ }^{2}$ Department of Public Administration, Uludag University, Turkey
}

\begin{abstract}
This study examines the mutual relations between risk, risk society and types of disaster, after having defined risk and the risk society, then proceeding to analyze a range of disaster management models that are currently applied in Turkey and other countries. An empirical survey about the last major disaster that occurred in Turkey is carried out. Consequently, a new, effective and functional integrated disaster management model for Turkey is proposed.

The term 'risk society' describes the inevitable new hazards produced by industrial society's process of development. The risk society brings not only hazards and risks that are not familiar and have not been faced before, but also prosperity and benefits for the members of the risk society. Natural and man-made disasters affect human beings more than in pre-industrial society and produce distinctive impacts on and changes in the psychological structure of urban society after disasters.

The disaster management system applied in the risk society should be different from classical systems. While implementing a disaster management model, specific types of disaster that may occur in urban areas should be considered. The model should include swift response, efficiency and practicality. As a conclusion of all these studies, a new, effective disaster management model applicable to Turkey is proposed.
\end{abstract}

Keywords: risk society, natural and man-made disasters, disaster management, crisis management, Turkey. 


\section{Introduction}

Disasters are events that humanity frequently encounters and cannot avoid. Disasters become significant because of the damage they cause to people, their environment and the places where they live. In previous developmental stages of society, there were only natural disasters, whereas in the modern industrial society man-made disasters occur as well. With these characteristics, we can say that the disasters we encounter nowadays have taken on new and different features.

\subsection{The general aim and target of the study}

The study aims at revealing that the modern urban society, which developed as a result of the industrialization period, includes the characteristics of the "risk society", emphasizing that disasters will inevitably occur together with other risk types in our lives in the risk society. With this perspective, emphasizing the need for a new and effective disaster management system in modern society, and building on comparative surveys in leading industrial countries and a field survey in Turkey, the aim is to suggest a "Disaster Management Model" that will be able to answer this need for Turkey, which is frequently exposed to natural disasters.

\subsection{The importance and originality of the subject}

Turkey is among the countries that face natural disasters very often. As a reflection of its geographical and physical characteristics, this situation underlines the importance of disaster management for Turkey. Experiencing several earthquakes and similar disasters in every decade, the case of Turkey questions current disaster management systems and indicates the need for a new one. This study proposes a required disaster management system for Turkey in an independent way through original research and analysis. Data and propositions in this paper clearly indicate the importance of the study.

\subsection{The reason for the subject of study}

Natural and technological disasters put social life in a position where it is impossible to manage by normal government mechanisms. As a consequence, throughout the world, separate and special management methods are used in the pre-disaster phases and on the occurrence of disasters in the management and response phase. These applications of a "Disaster Management Model" vary depending on a country's sociological, geopolitical and administrative differences.

Because of such differences and characteristics of disasters and disaster management systems, this study is necessary for developing a new, efficient and feasible disaster management model proposition for Turkey. This study raises points of the utmost importance for Turkey in its proposals for an efficient management system in this area. 


\subsection{Hypothesis of the study}

As it is impossible to avoid risks and disasters in modern urban societies, a new and different disaster management model is required for dealing with disasters and reducing the possible damage to the minimum. Being old, inefficient and unintegrated, the current disaster management system used during actual disasters in Turkey is not successfully functioning. We have in this study carried out an empirical investigation into the problems embedded in the current system. Then, keeping the data collected in focus, a new efficient and feasible disaster management system is proposed. Our proposal based on the results of this empirical study is considered to meet Turkey's specific requirements.

In short, the hypothesis of this study can be summarized as follows: In Turkey where very often disasters occur, since disaster management is not efficient enough during pre-disaster, disaster and post-disaster phases, a new and efficient management model is required. When designing this model, development of coordination, cooperation and institutional capacity should be provided first and the model should be implemented as a system in which it is possible to manage the disaster nationwide during all three phases (pre-disaster, disaster and postdisaster).

\subsection{Main sections of the study}

The study consists of six main sections including the introduction:

The second section gives conceptual definitions and develops the theoretical framework.

In Section 3, the disaster management systems of prominent countries from different areas that face frequent disasters are examined.

In Section 4 the current disaster management method of Turkey is analyzed. In this chapter where central and local disaster management structures are examined, the current insufficient and multi-centered structure is presented.

In Section 5, empirical research testing Turkey's current disaster management practice is presented and outcomes are explained. The outlook of the current system is evaluated by examining practices during the 1999 Marmara earthquake. Interviews and questionnaires are used in the empirical research that is carried out through contact with administrators who have participated in the disaster management. In this research, outcomes of these interviews are presented as a detailed summary.

In Section 6, the proposed model, which is designed in the light of the overall theoretical definitions and the data from area researches and their outcomes, is presented.

Finally, in the conclusion of the paper, disasters and necessary practices to respond to disasters are outlined and the construction of a new system of disaster management is presented. By trying to introduce a new disaster management model, we believe that we contribute to disaster management practices in Turkey and other countries. 


\section{Theorical perspective}

The first stage of the study presents the theoretical framework through terminological definitions. In this part, risk, risk society, disasters, and disaster risk are initially analyzed. Then the models of management, which are implemented in disaster situations, are outlined. In addition, the practical application of these models of management to public administration at times of calamity is explored.

The term "risk" is more commonly employed in the fields of finance and management; yet it is also made a primary focus in the fields of sociology and political science by Giddens and Beck: "The word 'risk' seems to have come into English through Spanish or Portuguese, where it was used to refer to sailing into uncharted waters" [1]. Beck [2] defines the term "risk" as a systematic confrontation with the threats caused by modernization period. As for Furedi, he draws attention to the connection of the word "risk" to danger, and defines it thus: "the term risk means the probability of damage, wound, illness, death and other negative consequences in connection with a particular danger" [3]. The term risk is used together with the words danger and harm in the fields of natural disaster and calamity management: "The emergence of challenging mechanisms to society and social life or the probability of their occurrence in the same place and at the same time bears significance in the evaluation of risk" [4].

The term "risk society" characterizes a developmental social process following from the development of modern industrial society [5], and it emphasizes that modernization incorporates not only benefits but also risks for humanity. One of the definers of this concept, Beck, "assumes and conceptualizes the risk society as a post-industrial society stage" [6]. Beck asserts that the risk society develops through several stages and that after these stages the industrial society will question itself by perceiving itself as a risk society [7]. This developmental stage, which is conceptualized as risk society, is an unavoidable process for the modern society. Each felicity produced brings along new and different risks [8].

The most important risks among those named as external and manufactured risks [9] are the risks, threats and dangers we are exposed to after disasters [10]. Disasters, which can be classified under the categories of natural and technological disasters, lead to dangers and risks that the modern city community in the industrial society is not used to. Disasters, being the number one risk in modern societies, are events that cause serious harm and loss with their occurrence.

Administrative bodies have been implementing different administration methods and techniques not applied under normal conditions to take account of the case of massive damage and dangers caused by disasters. Disaster management, emergency management [11, 12], crisis management, risk management in chaotic situations and shock management are further implementation methods seen in disaster managements [13, 14]. The processes of disaster management are arranged as follows: (a) Mitigation, (b) Preparedness, 
(c) Response and reaction to the disaster, (d) Recovery and reconstruction activities $[15,16]$.

It is possible to observe that the Disaster Management System is inadequately in its use against natural disasters in countries throughout the world, including Turkey. This system, which we can term a classic Disaster Management System, has been insufficient in intervention against and management of disasters. Therefore, the dimension of the trauma faced throughout natural disasters has been enormous. Surely, according to these critical results a new, applicable, and integrated disaster management system is needed.

\section{Disaster management systems across the globe}

In the second part of this study, the disaster management systems of countries that are frequently exposed to calamities in different parts of the world are analyzed. The geographic spread of these areas (America, Asia and the Far East) provides an opportunity to understand and compare calamities and disaster management systems. Understanding the disaster management systems in those countries will illuminate the proposed disaster management model that we will develop for Turkey. The countries whose disaster management models we analyzed are the USA, Russia, Japan, and Indonesia.

\subsection{USA}

The USA is one of the biggest countries in the world, having a large surface area and population. Technological calamities occur in USA together with natural disasters, which are often seen due to its large surface area and geographical location. It is stated that the calamities that took place among 1975-1998 resulted in 9000 losses of life and cost over 300 billion dollars [17]. Due to the fact that USA was defenseless against these calamities and they could not avoid them, it became an obligation to develop disaster management and organization. Besides the local and regional organizations, an organization that works on a national level is necessary.

In the USA, disaster management organization envisages a system that extends from local to center. Calamities, in the first instance, are seen as problems that should be solved by local organizations. After a disaster has occurred, local organizations address it. Then, units that belong to provinces and the Federal State step in. The USA possesses a disaster management organization (FEMA) which is centrally run by the Federal State. This organization is responsible for overall disaster management organization. This organization is attached to the US president. FEMA is authorized to struggle with all kinds of calamities on a national level and to manage disasters. It manages and coordinates operations before, during and after disasters.

Although FEMA is the general authority, it does not attempt to intervene in every kind of disaster. In order for FEMA to intervene in any kind of disaster, the budget that is required to deal with the disaster should exceed the economic resources of the particular state, and the state governor should demand help from 
the Federal government. As a result of the terrorist attacks on 11 September 2001, there were some changes in the structure of FEMA and it was transformed into a body that is concerned with security [18]. After this transformation, there have appeared many serious criticisms that Fema has moved away from the concept of disaster management and so has been ineffective in dealing with disasters.

\subsection{Russia}

The Russian Federation, which has the largest territory in terms of acreage, spreads from the Europe to the east part of the Asia and it has wide areas of steppe and forest. In terms of its climate, it has long and brisk winters and experiences climatic extremes, which can get as bad as disasters since some parts of its territory are close to the North Pole [19]. One of the two world powers during the period of Cold War, the Soviet Union as well as the USA entered a process of armament and the former founded a number of plants to produce nuclear energy and weapon. In the course of this process, people in the Russian Federation experienced serious disasters like the Chernobyl disaster and they faced technological risks [20]. Moreover, the historical development of Russia, its ethnic organization, its wide geography and geopolitical position, have caused Russia to experience very serious disasters. Thus, the structure of emergency and disaster and crisis management in Russia has developed until today incorporating consideration of its special conditions [21].

EMERCOM was founded in the years 1990 and 1992 by decree of the Russia president and special government regulation. The aim and the mission of this foundation is to carry out tasks in Russia dealing with emergencies and disasters and to this end to develop necessary regulations. After its foundation, an authoritative security council was founded which can coordinate these disaster tasks. In this council, which is presided over by the Russian President, the Chief of the General Staff is also one of the members. After a legal regulation in 1994, there were foundational changes in EMERCOM and it became the Russia Federal Civil Protection and the Ministry of Emergencies. This foundation works in line with military hierarchy and discipline, but has a civil role [22].

\subsection{Japan}

Japan is a country made up of many Islands where they have many earthquakes and other natural disasters. It has a land area of less than $1 \%$ of total Earth but more than $10 \%$ of all seismic energy generated comes from there. There are 86 active volcanoes in Japan, constituting $10 \%$ of the total active volcanoes on Earth. Earthquakes and volcano eruptions result in earthquakes, forming huge tides in the Pacific Ocean and threatening the Japanese Islands with Tsunami risks [23].

The disasters resulting from the geographic and geologic structure of Japan led to the formation of special treatment plans and policies for disasters. Disaster management policies were taken seriously and developed to protect against and prepare for disasters as well as for post-disaster intervention. After some major 
disasters, there were major amendments in legislation and plans for handling disasters.

In the structuring of disaster management operations, there is a Central Disaster Management Council that forms a top level of central administration. The General Directorate of Disaster Management is responsible for disaster issues in the center, and in the provinces, cities and municipalities are organized to handle disasters. There are local disaster management councils in these provinces. Local administration personnel, police and firefighter chiefs meet under the directorate of the governor or the mayor of the city.

\subsection{Indonesia}

Indonesia consists of more than 1700 Islands in South-East Asia. There are 5500 rivers; most of the worlds rain forests are here and there are 129 active volcanoes. Due to these geographical features, river floods, volcanic eruptions and major earthquakes occur quite often. Tsunamis occurring as a result of earthquakes threaten the islands and the people who live there. Because they encounter with disasters quite often they have formed a strong disaster management structure.

In Indonesia, a National Disaster Management Coordination Council (BAKORNAS PB) organizes, coordinates and carries out disaster management on a national level. Preparation and implementation of general plans is carried out by this unit in case of a disaster. Fighting against natural and manmade disasters and organizing aid during and after the disaster are all handled by this unit.

Local disaster management is handled on the level of towns and provinces. Emergency rescues and aid delivery activities during a disaster are handled by local disaster management organizations such as SATKORLAK PB and SATLAK PB. The responsibility again rests with the authorities to improve and rehabilitate the situation after a disaster.

\section{Disaster management organization in Turkey}

In this third section, existing disaster management systems in Turkey are studied. The structure for dealing with disasters that has existed since the establishment of The Turkish Republic developed in two channels after the Second World War. A study developed by The General Directorate of Civil Defense was later finalized by the establishment of The General Directorate of Disaster Affairs in 1957 resulting in the passing of a basic law on disasters. The recent establishment of TAY (The General Directorate of Emergency Management of Turkey) is a sure evidence of a multiheaded disaster management system in our country.

The development of Disaster management organization in Turkey grew in parallel with the development of the Civil Defense area. After the Second World War, Turkey joined NATO and led to an organization that is parallel to NATO countries' civil defense concept. The Civil Defense organization mainly focused 
on unarmed struggle with enemies behind the battlefield and also on protecting the civil public from the damage of war and can also try to compensate for the destruction caused by chemical and nuclear weapons. In this context, civil defense undertakes a struggle against disasters and hazards.

On the other hand, after the Second World War some renewals in the organization and concept of disaster management took place. In the 1950's, while basic legislation related to disaster management was passed, civil defense laws were also passed and related administrative structures were put into circulation. These developments in disaster management and civil defense in Turkey result in a structural imbalance between center and provinces (rural areas). Both of these units are very strong in the center but in the provinces they extend to very weak units. Reflecting the central organizational structure of Turkey, resources, personnel, decision-making and policy-making in the processes of disaster management are all handled by the central organizations.

However, the disasters are local and this central structure of decision making contradicts this reality. As a result of responsibility and authorization being in the hands of central organization, local administration, governors and district governors did not organize their units properly or just ignored the central organization.

Even within the central government authorities, there are different measures and systems in Turkey for managing disasters. Extraordinary situation management, crisis management, or disaster management procedures could be examples of this. As a reflection of these different structures organized for disaster management, we face a variety of different interventions during disasters. Different units undertake responsibility to intervene in disasters. For extraordinary situation management, the Prime Ministry Crisis Management Center, disaster management organizations or the Civil Defense Organization each would apply their own procedure, which they developed to cope with disasters. In addition, various ministries and institutions, such as the Ministry of Environment, the Ministry of Health, and the Turkish Atomic Energy Institution, would interfere in types of disasters that related to their activities. The management of disasters by central authorities leads to chaos with confusion, over which agencies have authority and responsibility in the actual management of disasters.

We can see similar problems when we project this diverse structure in the center to the provinces. There is more than one unit operating in disaster-related issues. In real disaster periods, no one seems to be responsible at an institutional level. With these characteristics, the disaster management system in Turkey can neither function properly nor can it perform successfully in actual cases.

\section{Empirical research: the existing and proposed disaster management systems}

In this fourth section, empirical research, which tests the Turkish disaster management system, is carried out. The real life (disaster) applications of the existing system are studied focusing on the main two earthquakes we 
experienced in 1999. Interviews and questionnaires were used to collect empirical data from the authorities who participated in disaster management. The results were tabulated and analyzed.

Fifty administrators who undertook certain responsibilities during 1999 Marmara Earthquake were interviewed face to face. The interview addressed four main areas. Firstly, the tasks and responsibilities of these personnel in the institutions where they work is discussed. Secondly, the roles and function of the institutions in case of a disaster is analyzed. Third the participants' views on the disaster management system and its application are studied. Lastly, their suggestions on a new disaster management model are sought.

The results of the first section show that $82 \%$ of them were administration officials who work for the central public organizations. Eighteen percent were representatives of local administration and NGOs. In addition $21 \%$ were governors, $45 \%$ were vice governors and district governors and other city administration officials. Six percent were civil defense organization personnel. Six percent of them worked for the Prime Minister's office, 6\% for the Ministry of Public Works, 12\% were mayors and vice mayors of local administration and $6 \%$ are NGO representatives. Almost all of the people interviewed were in charge of disaster management processes and actively involved during disasters.

In the second part of the research, the disaster management related roles and functions of the institutions - where the participants are currently employed have been assessed. A big majority of the participants have stated that postdisaster activities are of greatest interest to the institutions they work for. They have also added that the biggest number of joint projects these institutions undertake with regard to disaster management take place through coordination with the Directorate General of Disaster Affairs in the Ministry of Public Works, the Directorate General of Civil Defense in the Ministry of the Interior, the Turkish Armed Forces (TSK) and a number of other military institutions. The cooperation with the Crisis Management Center of the Prime Minister's Office, the Directorate General of Turkey Emergency Management of the Prime Minister's Office, and local governments has been stated to occur less often. While a big majority of the participants $(65 \%)$ maintained that it is vital to form a new structure in regard to disaster management, they also pointed out that the authority they are given under the current legislation is insufficient.

The third part of the research elicited the participants' opinions on the disaster management process and Turkey's disaster management system in general. In this part, the participants were also requested to state their opinions about the priority levels in the various parts of disaster management mainly categorizing them into two stages: $36 \%$ of the participants emphasized the significance of the pre-disaster preparation work, while $60 \%$ pointed out that both the pre-disaster and post-disaster tasks are of equal importance. In addition, almost all of the participants (98\%) found the pre-disaster preparation work in Turkey to be quite insufficient. Among the underlying reasons they have cited regarding this insufficiency are the out-datedness of the system $(32 \%)$, the fact that the institutions carrying out the disaster-related duties are not given clear tasks $(35 \%)$, and the over-complex and incomprehensible structure of the current 
disaster management system (18\%). It has also been stressed (by 62\%) that local governments should assume most of the responsibility for pre-disaster preparation work. Thirty-two percent of the participants found the post-disaster search and rescue operations and the reorganization work to be relatively successful, whereas $64 \%$ found them unsatisfactory. Additionally, 39\% have remarked that the post-disaster work should mostly be incumbent on local governments, while $61 \%$ have articulated that units operating under the central administration should shoulder this responsibility.

The participants with the opinion that the central administration should assume a greater level of authority and responsibility also stated that:

- gathering authority in disaster management under a single roof will eradicate the lack of coordination and the confusion over responsibility

- disaster management necessitates a disciplined and authoritarian structure and this structure can only be provided by central administrative bodies

- the financial resources, personnel, and technical support needed in times of disaster can only be supplied by the central administration.

Those, on the other hand, who stressed that local governments should assume a greater degree of authority and responsibility for disaster management and who emphasized the benefits therein, have stated that:

- local governments enjoy a greater degree of flexibility in their actions which contributes to speed and efficiency of response

- they are more likely to provide funds and resources and utilize them for all the disaster efforts to greater effect, and they can avert any misuse of resources by more closely monitoring and enhancing productivity

- they are able to more clearly and incisively determine the local problems owing to their proximity to these problems, and they can integrate the public into the administration.

In the fourth part of the research, the participations were requested to state their opinions about what kind of new disaster management model should be created for Turkey, and their opinions have been assessed. They have been asked to do this as implementers. As a result, most of them highlighted the importance of the restructuring of the system and that this could be the only solution to the present problems. While $16 \%$ asserted that the current system is out-of-date, obsolete and thus insufficient, 20\% drew attention to confusion over authority responsibility in the assignment of tasks, highlighting that the same authority and tasks are delegated to more than one institution.

In the answers provided to the question of how the roles and functions should be shared by the central administration and local governments, $43 \%$ said that the central administration should play more of a coordinating and supporting role while local governments should provide assistance in the implementation of the tasks. Forty percent contended that the Interior Ministry should direct and monitor the whole process of disaster management; while $31 \%$ stated that the Directorate General of the Turkey Emergency Management should control the 
process. In this case, we might well concur that the Interior Ministry should play a decisive role in the reorganizing and restructuring work that will take place concerning disaster management. This being the case, $48 \%$ insisted that the Interior Ministry should assume an active role while city and district governors the provincial representatives of the central administration - should bear the greatest responsibility in the reorganization of this task in the provinces.

In regard to the examination of the roles of local governments and civil society organizations in the organization of a new disaster management system, the majority of the participants $(68 \%)$ stated that local governments should assume a bigger range of roles in disaster management. They also remarked that local government should concentrate more on pre-disaster preparation work and damage reduction work. It has been further emphasized that civil society organizations should be more actively involved in disaster management and that they should contribute to and play a supporting role in the all disaster management work carried out by the central administration or local government.

This has brought out the necessity of public involvement in the organization of a new disaster management system. At the same time public involvement in disaster management should be strictly controlled by a management structure, which should determine in advance what kind of activities can be shared by the people. In addition, helping people to acquire a greater capacity for selfsufficiency in time of disaster is emphasized.

The participants were also asked to state their suggestions as to how Turkey can develop a disaster management system equipped with a greater degree of applicability to the specific risks faced by Turkey. The responses to this question have been classified under four main subtopics:

- The central administration should play the leading role in disaster management.

- There should be a single governing body on top of all others, called the "Top Administration".

- A scale model of this "top" administration should be implemented in the provinces.

- A new disaster management system should have a high level of efficiency, productivity, practicability and applicability while enjoying a sustainable level of integration.

Finally, in our empirical research, the participants were asked to state any other opinions about the current disaster management system and the related legislation. Among the various answers we obtained, the idea that "the legislation should be revised and amended, and in the amendment work there should be a single legal text on disasters and the administration should be gathered under a single roof," was expressed by 34\%. Other suggestions include opinions about pre-disaster work $(16 \%)$ and emphasis on the importance of the standardization of the post-disaster work was mentioned. What is particularly emphasized is that all the different units founded in Turkey for disaster management should unite under the same roof. 


\section{An applicable disaster management organization for Turkey: a new model}

The fifth part contains the final suggestions we have arrived at as a result of all the data acquired from the definitions, discussions and opinions included in the entirety of the research we have made. The chaos and incompetence in Turkey regarding the vital issue of disaster management have been indisputably leading us toward making new suggestions about how we should change the current system. This new system being functional, applicable, efficient and integrated has been cited among the most essential parameters. Our proposal for "An Applicable Integrated Disaster Management Model for Turkey,” is propounded in this part.

The new disaster management structure suggested for Turkey is thought of as a system that regards the center and the provinces as a single body. The central organization aims at uniting all the ministries, official institutions and foundations under a single roof in Turkey's unitary structure for more effective disaster management. Through this reorganization, which is considered to be a new unit, the disorder amongst the institutions in the center will be eradicated and the visible chaos in the fields of authority, duty and responsibility will be removed. Moreover, this unit is envisaged to have a hierarchical and disciplined structure in its workings.

It is thought that all units under other ministries concerning disaster management should be abolished, their functions to be conveyed to this new unit, which must function under the Ministry of Internal Affairs at the center. This structure, to be organized within the scope of Ministry of Internal Affairs as an "Emergency Situation and Disaster Management Unit", will undertake the role of standard setter, controller and coordinator. This new organization will put an end to structural chaos, multi-headedness and disorder. Moreover, we expect that it will also abandon the different boards that create different decisionmaking processes.

Field organization of disaster management will be rearranged under the aegis of province and sub-province administration. "Province and Sub-province Emergency Situation and Disaster Management Centers" will be established with duties to be performed under the charges of the governor and district governor. Province emergency situation and disaster management centers will be in charge of basic disaster management tasks on a provincial level. They will coordinate and direct the activities of disaster management units, local governments and other state institutions and organizations, in all sub-provinces on a province-wide scale.

Province emergency situation and disaster management centers will consist of two main bodies and activity units under them. A "Province Disaster Management Assessment and Decision Body" will perform the function of general decision making with regard to the application of specific disaster management strategies. A "Province Disaster Management Executive Body" will be the other main body, undertaking the direction and co-ordination of local 
disaster management strategies with decisions made by the head body concerning disaster.

The province disaster management assessment and decision making body will perform and operate under the presidency of the governor. Top managers of institutions and organizations concerned directly with disaster in provinces together with heads of local government will participate in the decision-making body. In addition to these, heads of public units required in accordance with the nature of disaster will be invited to participate by the governor. A parallel structure will also be created under the presidency of district governors in subprovinces. The province disaster management, assessment and decisionmaking body will organize meetings and take decisions as required in case of need. Consequently, it will perform its functions as part of the province emergency situation and disaster management center, so as not to produce a different independent organizational structure.

The province emergency case and disaster management center and executive body will carry out duties under the presidency of the Deputy Governor and include senior managers and agents of units involved in disaster work in the province. The province municipality, military units, security forces, public works units, agents of health and civil defense will appear in the executive body. According to the type of disaster, agents of technical units and other unit agents who need to be assigned will join in the duties. Local governments will actively participate in disaster-management duties with the input of technicians and workers.

The province emergency situation and disaster management center and executive body will have a regular working system ensuring continuity. It will be responsible for planning all pre-disaster, disaster, and post-disaster solutions to be applied in the province. It will coordinate and ensure the proper enactment of all disaster-management activities to be carried out during and post-disaster. The disaster management center and executive bodies will carry out planning functions and ensure proper administrative structures are in place as well as being actively involved during the disaster phase.

While the province disaster management and executive body is planning the activities that will be required during a disaster, it will interact with sub-units. These units, which we will term Province Disaster Management and Executive Body Activity Units, are composed of these:

- Disaster loss and risk assessment unit

- Disaster phase and security coordination unit

- Logistic support and relief coordination unit

- Temporary quartering unit

- $\quad$ Rescue, wreck removal, substructure intervention and coordination unit

- Post-disaster civic improvement unit

- Psychological support, rehabilitation and social aid unit

The above-mentioned units will undertake all predisaster and postdisaster duties to be performed by the province emergency situation and disaster management center. Tasks to be performed by all institutions, particularly 
predisaster tasks in provinces will be channeled and coordinated through these units. They will also orientate disaster preparation plans towards specific tasks that will be carried out in all phases of the disaster.

Those activity units that will take a less active role in predisaster tasks will contribute to disaster tasks with all their facilities and resources in during and after disasters. Accordingly to this function, they will maintain aforetime readiness to supply the facilities and resources of their cadre on a province-wide level.

The parallel structural body will be organized on a district level. District governors will be responsible for this unit, which will co-ordinate all disaster tasks at this level. The province emergency case and disaster management center will subsidize disaster tasks to which the resources of subprovince are not allocated.

Other civil organizations will be invited under the umbrella of the province emergency situation and disaster management center. The participation of the public will be provided for in of predisaster and postdisaster, with NGOs coordinating these tasks and contributions. A press and information unit will be built to ensure that the public are properly informed of disaster management activities and of arrangements and schedules for evacuated people (disaster victims) who live in the disaster-stricken area.

The basic text that will be followed in organizing tasks of emergency situation and disaster management will be a disaster action plan. These plans, which will provide management with an integrated and coherent strategy, must be prepared pre-disaster and tested with case studies at specific periods, to be kept ready for putting into practice. These plans will be put into force on a central executive level in the province emergency situation and disaster management center and by the province activity units in order to benefit the coherent organization of disaster-management tasks in the field.

It seems that in disaster management tasks, for efficient and applicable plans to be carried out, differences of duty and authority need to be clearly defined and explained. A planning system in which specified tasks with which particular bodies are charged are clearly explained and integrated for coherent response is to be preferred over a range of multiple and conflicting disaster plans implemented by units. It is thought preferable that authority on planning of specific tasks should be devolved to the governorships in field units, with the central body assuming the function of determining general policies to guide all these disaster-management activities.

\section{Concluding remarks}

Our study would like to set out the following results:

- Modern industrial communities have many risks in their nature alongside the benefits they produce. These risks bring threats and dangers that humanity has never seen before. Natural and man-made disasters bring different kinds of risk. 
- The disaster management system in modern city communities needs to be rearranged according to new developments and improvements. A disaster management model that is new, efficient and integrated is needed to combat disasters and their effects.

- The disaster management system currently applied in Turkey shows features out of step with new developments, being multi-headed, and disorderly and overly focused on central organizations. A structure that is field-oriented and devolved to integrate local organizations is obligatory for the proper function of the system.

- The great majority of the fifty participants in the empirical investigation have seen the current centralized executive system as unavailing, being antiquated, disorganized, and awkward.

- The participants in the empirical investigation have avowed the necessity of creating a new disaster management system for Turkey. It has been expressed that this would entail the integrated co-operation of a single central structure, the local governments with (Provincial Directorates with Governor and District Governorship), field organizations, with central policy can be effectively implemented and structured at a local level in this system.

- It has been claimed that more accountability is necessary, with a transparent structure of disaster management with clear allocations of responsibility to be implemented for Turkey.

- As a result of our findings, a "Disaster Management Model applicable for Turkey" has been suggested.

- The organization of this disaster management model shows a structure that encompasses both field and center. The nuts and bolts of the system will be created through disaster management organizations to be established on the province and subprovince levels. The provincial and subprovincial structures will be organized as parts of a civic center, with local governments and other local institutions and organizations involved in the structuring of disaster management. In addition, managers will have a remit to allow for greater participation of the public though the Non-Governmental Organizations (NGO).

- National responsibility for disaster management organization will be gathered under one roof in the administrative center. This organization, preferably under the ministry of internal affairs, will undertake the coordination and direction of disaster-management policy, making general decisions concerning disaster on a country-wide level and laying down general policies.

- It is suggested that this body be established as the "General Directorate of Emergency Situation and Disaster Management" allied with the Ministry of Internal Affairs in the center. This body will take on all tasks concerning disaster management policy, abolishing units concerning disaster in all other executive units and institutions.

- "Province Emergency Case and Disaster Management Centers" will be established in provinces. These centers will work in alliance with the 
provincial governors and all tasks concerning disaster to be carried out in a province will be directed and coordinated by this unit. Concordant parallel structures will be established also in subprovinces.

- Province Emergency Case and Disaster Management Centers will be composed of two main organs. These are the Assessment and Decision Body of Province Disaster Management and the Province Disaster Management Executive Body. While the first body undertakes the function of coordinating all practical tasks and duties and makes general decisions concerning disaster management, the second body will undertake all executive duties concerning disaster management. So, the possibility of confusion between the decision-making and executive bodies will be removed.

- The organization of the Province Emergency Case and Disaster Management Centers must be comprehensible and simple. The main reason for problems is the difficulty of comprehending how the policies and directions of the central executive system should be applied in local areas. The simplicity of the system to be suggested will provide greater effectiveness and practicality of disaster-management measures.

- The new disaster management system should be organized and implemented with full participation of local institutions in the field instead of centralizing all resources. In addition, post-disaster urban regeneration must be directed and implemented in the field.

- The new types of risk and disaster seen in urban areas vary from those expected by the classical system and require the establishment of a new disaster management system. Today, disaster management systems must be designed to cope with these new disaster situations, which are specific to the historical process of industrial society.

\section{References}

[1] Giddens, A., Elimizden Kaçıp Giden Dünya, Çev. Osman Akınhay, Alfa Yayınları: İstanbul, 2000, p.36.

[2] Beck, U., Risk Society, Towards a New Modernity, Sage Publications: California, 1999, p.21.

[3] Furedi, F., Korku Kültürü, Çev. Barış Yıldırım, Ayrıntı Yayınları: İstanbul, 1992, p.43.

[4] Torrence, R., \& Grattan, J., The archaelogy of disaster: Past and future trends. Natural Disasters and Cultural Change, ed. Torrence, R., \& Grattan, J., Routledge: London, p.1-18.

[5] Beck, U. Siyasallığın İcadı çev. Nihat Ünler, İletişim Yayınları, İstanbul, 1999, p.19.

[6] Joffe, H., Risk and "the Other". Cambridge University Press: Cambridge, 1999. p.6.

[7] Adam, B., Beck, U., \& Loon, J.V., The Risk Society and Beyond, Sage Publications: London, 2000, p.223. 
[8] Beck, U., Siyasallı̆̆ı İcadı, çev. Nihat Ünler, İletişim Yayınları, İstanbul, 1999, p.35.

[9] Giddens, A., Elimizden Kaçıp Giden Dünya, Çev. Osman Akınhay, Alfa Yayınları: İstanbul, 2000, p.41.

[10] Giddens, A., Elimizden Kaçıp Giden Dünya, Çev. Osman Akınhay, Alfa Yayınları: İstanbul, 2000. p.41.

[11] Yılmaz, A., Afet Yönetimi, Pegem A Yayınları: Ankara, 2003, p.42.

[12] Waugh Jr. W., \& John Hy. R., Introduction to emergency management, Handbook of Emergency Management, ed. Waugh Jr. W., \& John Hy. R., Greenwood Press: Westport CT, 1990. p. 1-10

[13] Gottschalk, J., Crisis Management, Capstone Publishing: Oxford, 2002, p.6.

[14] Littlejohn, R.F., Crisis Management "A Team Approach", AMA Membership Publication Division: New York, 1983, p.9.

[15] Drabek, T. E., The Professional Emergency Manager, Colorado, Institute of Behavioral Science University of Colorado, Colorado, 1987, p.22.

[16] Qarantelli, E. L., Urban vulnerability to disaster in developing countries: managing risks. Building Safer Cities, ed. Alcira Kreimer, The World Bank, Washington D.C. 2003, p. 211-231.

[17] Cutter, Susan L. (2000) "The Changing Nature of Risk and Hazards", American Hazardscapes, ed. Cutter, Susan L. Joseph Henry Press: Washington D.C., 2000, p. 1-12.

[18] Waugh Jr., William L., Living with Hazards, Dealing with Disaster, M.E. Sharpe, New York, 2003, p.26-32.

[19] McGuire, B., World Atlas of Natural Hazards, Arnold: London, 2004, p. 33-35

[20] Porfiriev, B., Disaster Policy and Emergency Management in Russia, Nova Science: New York, 1998, p.131.

[21] Porfiriev, B., Disaster Policy and Emergency Management in Russia, Nova Science: New York, 1998, p.112-114.

[22] www.adrc.or.jp

[23] Nishikawa, S., Asya'da toplam afet risk yönetimi (TDRM) ve Japonya afet yönetimi idari sistemi. 51. Dönem Mülki İdare Amirleri Afet Yönetimi Semineri Notlarl, Ankara, 2003, p.1-41. 